\title{
Peran Demokrasi Dalam pelayanan Kesehatan Bagi Masyarakat Pengguna BPJS Kesehatan
}

\author{
Rosita Silfiani \\ Institut Ilmu Kesehatan STRADA Indonesia \\ rositasilfiani@gmail.com
}

\begin{abstract}
Abstrak
Demokrasi merupakan bentuk pemerintahan dimana semua warga negara memiliki hak yang sama dalam pengambilan keputusan yang dapat mengubah hidup mereka. Demokrasi mengizinkan warga negara berpartisipasi baik secara langsung maupun perwakilan. Begitu halnya dalam mendapatkan pelayanan kesehatan bagi masyarakat pengguna BPJS kesehatan mereka juga mempunyai hak dan kebebasan yang sama untuk memperoleh pelayanan kesehatan yang baik. Pelayanan kesehatan merupakan sebuah pelaksanaan pemeliharan kesehatan dalam rangka mencapai derajat kesehatan yang baik untuk individu maupun masyarakat dengan secara optimal. Badan Penyelenggara Jaminan Kesehatan Sosial Kesehatan (BPJS Kesehatan) adalah badan hukum public yang bertanggung jawab kepada presiden dan berfungsi menyelenggarakan program jaminan kesehatan bagi seluruh penduduk Indonesia.
\end{abstract}

Kata Kunci : Demokrasi, Pelayanan Kesehatan, BPJS Kesehatan 


\section{Latar Belakang}

Demokrasi sering kali dikaitkan dengan kegiatan politik serta kebijakan yang berhubungan dengan tatanan politik. Namun bila kita membatasi pengertian demokrasi hanya dalam konteks politik, yang berarti menyederhanakan makna kehidupan manusia hanya dalam aspek tersebut. Memahami kehidupan manusia dengan cara meninjau dari aspek politim tentu sangat tidak realistis. Dalam kehidupannya, seorang manusia tidak hanya berhubungan dengan masalah politik saja, tetapi juga masalah-masalah lain. Tuntutan penegakan demokrasi dan hak asasi manusia, merupakan arus yang sangat kuat. Dalam situasi semacam itu, pemerintah harus saar betul bahwa tidak mungkin menyelesaikan masalah yang sangat komplek sendirian.

Demokrasi merupakan bentuk pemerintahan dimana semua warga negara memiliki hak yang sama dalam pengambilan keputusan yang dapat mengubah hidup mereka. Demokrasi mengizinkan warga negara berpartisipasi baik secara langsung maupun perwakilan. Begitu halnya dalam mendapatkan pelayanan kesehatan bagi masyarakat pengguna BPJS kesehatan mereka juga mempunyai hak dan kebebasan yang sama untuk memperoleh pelayanan kesehatan yang baik.

Program BPJS (Badan penyelenggara Jaminan Sosial) merupakan sebagai upaya dalam pemenuhan hak warga negara atas pelayanan kesehatan sebagai bentuk upaya untuk mengayomi masyarakat, mulai dari kalangan kecil yang mengalami kesulitan dalam mendapatkan pelayanan kesehatan.

\section{Kasus/Masalah}

Berdasarkan uraian latar belakang diatas maka dapat di rumuskan masalah sebagai berikut: Bagaimana peran demokrasi dalam pelayanan kesehatan bagi masyarakat pengguna BPJS kesehatan.?

\section{Tinjauan Pustaka}

\subsection{Pengertian Demokrasi}

Istilah demokrasi pertama kali diciptakan oleh sejarawan Yunani Herodotus pada abad ke-5 SM. Demokrasi berasal dari kata "demos" (masyarakat) dan "kriteria" (aturan dan kekuasaan). Menurut Lane dan Errsson, demokrasi berarti kekuasaan di tangan rakyat atau pemerintahan oleh dan untuk mayoritas. 
Menurut Sidney Hook demokrasi adalah bentuk pemerinahan dimana keputusan-keputusan pemerintahan yang penting secara langsung atau tidak langsung didasarkan pada kesepakatan mayoritas yang diberikan secara bebas dari rakyat dewasa.

Pada dasarnya demokrasi adalah hal yang dapat memberikan peluang kepada masyarakat untuk senantiasa berjuang dang menyampaikan suara hatinya sehingga mendapatkan hak dan kewajiban dalam menjalani kehidupan, artinya masyarakat mempunyai kebebasan dalam memperjuangkan hak-hak mereka dalam berbagai persoalan.

\subsection{Pengertian BPJS}

Badan Penyelenggara Jaminan Kesehatan Sosial (BPJS) sebelumya dikenal dengan nama Askes yang dikelola oleh PT Askes Indonesia, PT Askes Indonesia berubah nama menjadi BPJS Kesehatan sejak tanggal 01 Januari 2014. Menurut UU No 24 tahun 2011 tentang BPJS pasal 7 ayat (1) dan ayat (2), pasal 9 ayat (1) dan UU No 40 tahun 2011 tentang SJSN, pasal 1 angka 8, pasal 4 dan pasal 5 ayat (1). Badan Penyelenggara Jaminan Kesehatan Sosial Kesehatan (BPJS Kesehatan) adalah badan hukum public yang bertanggung jawab kepada presiden dan berfungsi menyelenggarakan program jaminan kesehatan bagi seluruh penduduk Indonesia termasuk orang asing yang bekerja paling singkat 6 (enam) bulan di Indonesia.

Badan Penyelengara jaminan sosial Kesehatan (BPJS Kesehatan) adalah Lembaga penyelenggaraan jaminan sosial sehingga dengan jaminan sosial resiko finansial yang dihadapi seseorang, baik karena memasuki usia produktif, mengalami sakit, kecelakaan bahkan kematian, akan diambil alih oleh Lembaga penyelenggara jaminan sosial.

\subsection{Bentuk Pelayanan Kesehatan BPJS}

Setiap peserta berhak untuk memperoleh Jaminan Kesehatan yang bersifat komprehensif (menyeluruh) yang terdiri dari :

1) Pelayanan kesehatan pertama, yaitu Rawat Jalan Tingkat Pertama (RJTP) dan Rawat Inap Tingkat Pertama (RTP)

2) Pelayanan kesehatan rujukan tingkat lanjutan, yaitu Rawat Jalan Tingkat Lanjutan (RJTL) dan Rawat Inap Tingkat Lanjutan (RITL)

3) Pelayanan persalinan 
4) Pelayanan gawat darurat

5) Pelayanan ambulans bagi pasien rujukan dengan kondisi tertentu antar fasilitas kesehatan

6) Pemberian kompensasi khusus bagi peserta di wilayah tidak tersedia fasilitas kesehtan memenuhi syarat

\section{Pembahasan}

4.1. Peran demokrasi dalam pelayanan kesehatan bagi masyarakat pengguna BPJS kesehatan

Pelayanan kesehatan merupakan sebuah pelaksanaan pemeliharan kesehatan dalam rangka mencapai derajat kesehatan yang baik untuk individu maupun masyarakat dengan secara optimal. Dalam pelaksanann pelayanan kesehatan tersebut terdapat interaksi antara pasien, tenaga kesehatan dan juga sarana kesehtan.

Pelayanan kesehatan yang diselenggarakan oleh pemerintah harus mampu mendorong masyarakat untuk mempertahankan eksistensinya, sehingga dapat memacu masyarakat untuk mengembangkan system pemerintahan yang baik dan demokratis. Prinsip-prinsip demokrasi melekat pada pemerintahan yang baik, yang menempatkan kekuasaan di tangan rakyat bukan sekehendak penguasa semata.

Dari pihak masyarakat pengguna BPJS mereka perlu menunjukkan semangat untuk hidup sehat. Mereka harus menghilangkan rasa takutnya untuk menyampaikan kritik, saran, atau pendapat atas sesuatu yang dirasakan baik bagi kesehatan diri dan bagi bangsanya, sekalipun -endapat tersebut berbeda dengan kebijakan pemerintah.

Pelayanan kesehatan mempunyai peran yang sangat penting dalam memelihara dan meningkatkan derajat kesehatan. Pelayanan kesehatan merupakan satu kesatuan yang utuh dan terpadu serta saling mempengaruhi dari struktur dan fungsi bagi pelayanan kesehatan yang terdapat di suatu negara.

Dan untuk mewujudkan pelayanan kesehatan yang baik di dalam suatu negara, diperlukan pemerintahan demokratis dan good governance yang memberikan ruang partisipasi bagi berbagai elemen masyarakat untuk ikut merumuskan apa yang terbik bagi kesehatan diri dan bangsanya. 
Bagi masyarakat pengguna BPJS juga memiliki hak dan kewajiban yang sama untuk memperoleh pelayanan kesehatan yang baik, tidak ada perbedaan antara pengguna BPJS dan Non BPJS dalam pemberian pelayanan kesehatan.

\subsection{Opini Penulis}

Peran demokrasi dalam pelayanan kesehatan bagi masyarakat pengguna BPJS kesehatan sangat diperlukan karena dengan adanya demokrasi maka tidak akan ada lagi perbedaan antara masyarakat pengguna BPJS maupun Non BPJS dalam mendapatkan pelayanan kesehatan yang baik.

Dengan adanya demokrasi dalam pelayanan kesehatan maka semua pengguna pelayanan kesehatan memiliki hak dan kewajiban yang sama, untuk memperoleh pelayanan kesehatan yang baik, tanpa adanya perbedaan apapun, sehingga dapat memperleh pelayanan yang sesuai dengan fasilitas yang seharusnya diberikan, tanpa membedakan berasal dari kalangan manapun.

Adanya demokrasi dalam pelayanan kesehatan juga dapat memberikan kesempatan bagi masyarakat pengguna BPJS untuk dapat memberikan suaranya mengenai kritik maupn saran apabila terjadi ketidak adilan dalam pemberian pelayanan kesehatan bagi pesrta BPJS dengan Non BPJS.

\section{Kesimpulan}

Demokrasi tidak hanya berkaitan dengan dunia politik saja akan tetapi juga berkaitan dengan dunia kesehatan khususnya pelayanan kesehatan. Karena sejatinya demokrasi memiliki peran penting dalam pelayanan kesehatan. Dengan adanya demokrasi masyarakat mampu dan lebih berani dalam memberikan suara mengenai kritik ataupun saran guna tercapainya pelayanan kesehatan yang baik, karena semua memiliki hak dan kewajiban yang sama. 


\section{Daftar Pustaka}

Ardita, M. (2020). Tanggung jawab Negara Terhadap jaminan kesehatan dalam Perpektif Hak Asasi Manusia. Jurnal HAM, 11(2), 319-330

GULO, E. O (2015). Implementasi Peraturan BPJS Kesehatan Nomor 1 Tahun 2014 Tentang Penyelenggaraan jaminan Kesehatan di kantor BPJS Kesehatan Cabang Gunungsitoli Kepulauan Nias Provinsi Sumatera Utara. Studi pada pelayanan kepesertaan public, $3(1)$

Ichsan, M. (2014). Demokrasi dan Syura : Prespektif Islam dan barat. Substantia : Jurnal IlmuIlmu Ushuludin, 16 (1), 1-12

Oktoriani, EN, Sutrisno, J., Mayasari, E, \& Sodik, MA (2018). Analisis Fleksibilitas kelengkapan rekam medis untuk melengkapi klaim BPJS kesehatan RS baptis kota Batu. Jurnal Penelitian Global Kesehatan Masyarakat, 3 (1), 46-53

Matondang, R W. demokrasi Indonesia

Silfiani, R. (2021). Peran Penting Persatuan dan Kesatuan Dalam mewujudkan Program Gerakan Masyarakat Hidup Sehat (GERMAS)

Silfiani, R. (2021). Kewajiban masyarakat mematuhi himbauan Larangan merokok Saat berada di fasilitas Pelayanan Kesehatan Sebagai Upaya penerapan Kawasan Tanpa Rokok

Sodik, M.A, Suprapto, S.I., \& Pangesti, D. (2013). Faktor-faktor Yang Berhubungan Dengan Pelaksanaan Pelayanan Prima Pegawai Di RSui Orpeha Tulungagung. STRADA Jurnal Ilmiah Kesehatan. 2 (1), 24-32

Undang-undang Nomor 24 tahun 2011 Tentang Badan Penyelenggaraan Jaminan Sosial (BPJS) Kesehatan 
